\title{
Distribution of the Rough-Toothed Dolphin (Steno bredanensis) around the Windward Islands (French Polynesia) ${ }^{1}$
}

\author{
A. Gannier ${ }^{2,3}$ and K. L. West $2,4,5$
}

\begin{abstract}
The rough-toothed dolphin (Steno bredanensis) has been described as a primarily pelagic cetacean species that is found in tropical and subtropical oceans throughout the world. Information on distributional patterns or habitat preference in most regions where $S$. bredanensis has been reported is limited. This study reports on the distribution of S. bredanensis around the Windward Islands of French Polynesia. Data were obtained from vessel surveys between 1996 and 2000, where rough-toothed dolphins were sighted 38 times. Group sizes of rough-toothed dolphins ranged between 1 and 35 individuals, with an average size of 10.8 individuals. When corrected for effort, results indicated that in French Polynesia S. bredanensis is found over a wide area but is more commonly distributed inshore than offshore. Rough-toothed dolphins were usually sighted 1.8 to $5.5 \mathrm{~km}$ from the barrier reef, in water depths between 1,000 and $2,000 \mathrm{~m}$. Our results also demonstrate the year-round presence of this species around Tahiti and Moorea. Steno bredanensis has been reported in many oceanic archipelagos, and our findings may provide insight into preferred habitat and small-scale oceanographic conditions associated with regions where this cetacean species is relatively abundant.
\end{abstract}

INFORMATION ON rough-toothed dolphin (Steno bredanensis) distributions is limited, but published reports that include this species are quite widespread (Miyazaki and Perrin 1994). Steno bredanensis is rarely the focus of field studies but is often mentioned from a few

${ }^{1}$ Funding support for this project was provided by the Laboratoire Terre-Océan at the Université de la Polynésie française, Delegation a la Recherche of the Territoire de Polynésie française, Sea World, and donations by Hawaiian Airlines. Dolphin Quest Inc. supported K.L.W.'s Ph.D. dissertation, of which this work is a part. Manuscript accepted 20 February 2004.

${ }^{2}$ Laboratoire Terre-Océan, U.P.F., BP6570 Faaa Aeroport, Tahiti, French Polynesia.

${ }^{3}$ Centre de Recherche sur les Cétacés, Marineland, 306 avenue Mozart, 06600 Antibes, France.

${ }^{4}$ University of Hawai'i, Department of Physiology, John A. Burns School of Medicine, 1960 East-West Road, Biomed T-608, Honolulu, Hawai'i 96822 (phone: 808-230-8976; fax: 808-956-9722; e-mail: kristiwest@ earthlink.net).

${ }^{5}$ Corresponding author.

Pacific Science (2005), vol. 59, no. 1:17-24

(C) 2005 by University of Hawai'i Press

All rights reserved sightings. Although it is present in almost all tropical and subtropical regions, cetacean sighting data suggest that $S$. bredanensis is not a particularly common species in any area (Au and Perryman 1985, Hewitt 1985, Wade and Gerrodette 1993, Miyazaki and Perrin 1994, Mullin et al. 1994).

Previous reports on the distribution of rough-toothed dolphins are primarily from the eastern tropical Pacific, where very large regions of open ocean waters were surveyed. These studies have extended over 50 degrees of latitude, and for this open-ocean environment a large-scale distribution map for $S$. bredanensis has been generated from approximately 40 sightings (Wade and Gerrodette 1993). Other large-scale surveys in the eastern tropical Pacific indicate the presence of $S$. bredanensis in relatively low abundances compared with other delphinid species in that area (Au and Perryman 1985, Hewitt 1985). Cetacean surveys covering large areas of the western tropical Indian Ocean have also mapped S. bredanensis sightings; there the percentage of cetacean abundance represented by this species appears similar to that 
in the eastern tropical Pacific and the Gulf of Mexico, where this species is also present (Ballance and Pitman 1998). An aerial cetacean survey in the Gulf of Mexico documented only a single $S$. bredanensis sighting but in a water depth very similar to that of the inshore areas of French Polynesian islands $(\sim 1,000 \mathrm{~m})$ (Mullin et al. 1994, Gannier 2000).

Although S. bredanensis distributions have been assessed over the wide eastern tropical Pacific and this may allow for insight into preferred habitat associated with largescale oceanographic conditions, smaller-scale studies on the distribution of this species have yet to be undertaken. In French Polynesia, cetacean surveys have indicated that $S$. bredanensis is the second most commonly ob- served species after Stenella longirostris (Gannier 2000). This provides an opportunity to investigate the habitat preference of this species around small oceanic islands. Based on multiple sightings of rough-toothed dolphins and on sampling effort spread over 4 years, this study reports on seasonal and temporal variation in distribution around the islands of Tahiti and Moorea.

\section{MATERIALS AND METHODS}

\section{Area of Study}

The study focused on Tahiti and Moorea in the Windward Islands (Society Archipelago), located at a latitude of $18^{\circ} \mathrm{S}$ and a longitude of $150^{\circ} \mathrm{W}$ (Figure 1). Both inshore and off-

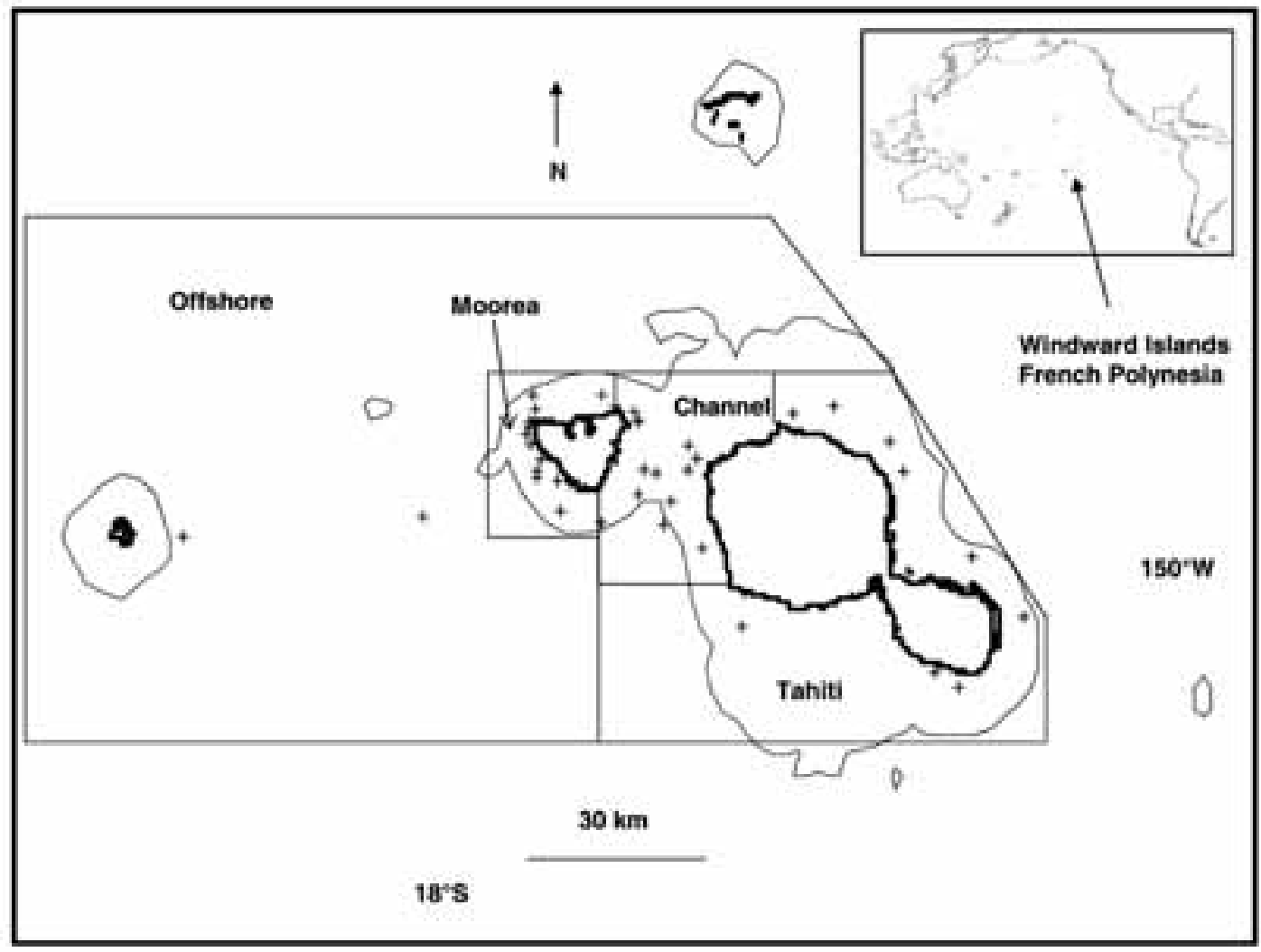

FIgure 1. Windward islands of Moorea and Tahiti located within the French Polynesian archipelago. Survey regions were categorized as channel, Moorea, Tahiti, and offshore areas. + indicates sighting location of Steno bredanensis. 
shore areas were surveyed. Due to the $12-18^{\circ}$ slope of these volcanic islands, the water rapidly reaches depths in excess of 2,000 m within the inshore area. Oceanic waters are oligotrophic (Longhurst 1999) but passes may provide nutrients into the photic zone and edge effects may cause local eddyinduced vertical mixing as shown around several tropical oceanic islands (Aristegui et al. 1997). The offshore area lies beyond $10 \mathrm{~km}$ of the barrier reef, with waters generally deeper than 3,000 m. Water masses are characterized by a very deep (200-300 m) and stable thermocline, but the sea surface temperature features a substantial seasonal change, with lower values of $25-26^{\circ} \mathrm{C}$ in August-September and higher temperatures of $29-30^{\circ} \mathrm{C}$ in February-April (non-ENSO situation).

The study area was divided into four regions to investigate distribution of roughtoothed dolphins (Figure 1). The first region was described as the channel located between the islands of Tahiti and Moorea; the second covered the rest of Moorea, which is essentially a leeward area, and extended up to 10 $\mathrm{km}$ from shore. The third region comprised all areas off Tahiti, except for the channel, which was primarily a windward exposure and also extended to $10 \mathrm{~km}$ from shore. The last region was defined as offshore waters, including areas surveyed that were more than $10 \mathrm{~km}$ from shore (Figure 1).

A series of 11 surveys were conducted between March 1996 and May 2000 using a $12 \mathrm{~m}$ sailboat. Sampling took place when wind speed was less than or equal to Beaufort 4, primarily using diesel propulsion at an average speed of $9.5 \mathrm{~km} \cdot \mathrm{hr}^{-1}$. Both inshore and offshore strata were sampled, and zigzag tracks were conducted around the islands whenever possible. A GPS (global positioning system) was used for positioning and navigation. During the surveys, two or three observers stood on the deck, about $2 \mathrm{~m}$ above sea level, and searched the side and frontal sectors. Position was recorded approximately every $3 \mathrm{~km}$, as well as wind, sea state, and relative cloud cover. When cetaceans were sighted, a GPS position was recorded immediately and radial distance and bearing were estimated. Schools of rough-toothed dolphins were approached systematically to estimate school size, composition, and pod activities.

\section{Data Processing}

Data obtained from sampling were entered into a database (Dbase IV) and made compatible with Oedipe Ifremer Mapping System (Massé and Cadiou 1994), also used for data poststratification and effort calculations. Bottom depth and distance to the barrier reef for each sighting were obtained from nautical charts issued by SHOM, the French Navy Hydrographic Service.

For a given survey protocol (i.e., same platform and same number of observers) and a given species, the assumption of constant dolphin detectability holds if sighting conditions are constant. Because wind in excess of Beaufort 3 may have adverse effects on the detection of small cetaceans (Hiby and Hammond 1989, Buckland et al. 1993), only survey efforts in conditions from Beaufort 0 to 3 were used to estimate sighting rates. Because our survey efforts were not homogeneous across the different strata (regions, periods, areas), distribution was effortcorrected: a mean sighting rate $\left(y_{p}\right)$ was computed, relating to the number of roughtoothed dolphins seen per kilometer. For estimating $y_{p}$, we retained the same sampling unit as that used for data recording and computed a sighting rate $y_{i}$ for each sample,

$$
y_{i}=n_{i} \cdot S_{i} / l_{i}
$$

where $n_{i}$ is the number of rough-toothed dolphin schools detected during the sample (in fact, $n=0$ or $n=1$ ), $S_{i}$ is the school size, and $l_{i}$ is the sample length.

The short sample length $(2-5 \mathrm{~km})$ was used to enable distribution to be estimated in small areas. Our data set included many 0 values, and the arithmetic mean was not adequate for estimating sighting rates. A Pennington estimator (Pennington and Berrien 1984) was used instead to compute average sighting rates. This estimator is based on the log-normal distribution of the nonzero values of a series of data (Aitchison and Brown 1957) and produces unbiased estimates of mean and 
variance in such cases. For a distribution of $n$ samples with $m$ nonzero values $(m>1)$, with $y_{m}$ the sample mean of the nonzero $\log _{\mathrm{e}}$ values and $s^{2}$ a sample variance of the $\log$ e values, Aitchison and Brown (1957) gave the estimate of the mean, $y_{p}$, as:

$$
y_{p}=m / n \cdot \exp \left(y_{m}\right) \cdot G_{m}\left(s^{2} / 2\right)
$$

Pennington (1983) gave the estimator of the variance, $\operatorname{var}\left(y_{p}\right)$ as:

$$
\begin{aligned}
\operatorname{var}\left(y_{p}\right)= & m / n \cdot \exp \left(2 \cdot y_{m}\right) \\
& \cdot\left[m / n \cdot G_{m}\left(s^{2} / 2\right)-(m-1 / n-1)\right. \\
& \left.\cdot G_{m}\left([m-2 / n-1] \cdot s^{2}\right)\right]
\end{aligned}
$$

where $G_{m}(x)$ is defined by:

$$
\begin{aligned}
G_{m}(x)= & 1+(m-1 / n) \cdot x \\
& +\sum_{2, \propto}\left[(m-1)^{2 j-1} \cdot x^{j}\right] / \\
& {\left[m^{j}(m+1)(m+3) \ldots\right.} \\
& (m+2 j-3) \cdot j]
\end{aligned}
$$

$T$-tests were then used to compare the mean $y_{p}$ estimates.

The seasonal variation of the roughtoothed dolphins sighting rate was investigated by processing data collected in the channel and Moorea areas, where the sampling effort was highest. The data were split into three temporal periods: a cold-water season (September to November), an intermediate season (December to February), and a warm-water season (March to May). Seasonal sighting rates were estimated as described previously.
RESULTS

Effort

Our total survey effort over the entire study area was $6,458 \mathrm{~km}$, and effective effort was calculated for each region and expressed according to Beaufort conditions experienced during the survey (Table 1). Average sighting conditions were similar (Table 1), except for the offshore area, where Beaufort 3 conditions were more prominent and composed a high percentage of the effective effort. Three different time periods during the year were investigated for seasonal effects in regions 1 and 2: an effective effort of 2,157 km of effort between September and November, $559 \mathrm{~km}$ between December and February, and 2,475 $\mathrm{km}$ during March to May.

\section{Sightings and Group Size}

Rough-toothed dolphins were observed 38 times during the study period. Smaller schools of $S$. bredanensis were more common than larger groups. Average school size was $10.8 \pm 9.5 \mathrm{SE}$ individuals with a range between 1 and 35 individuals. Out of our 38 total sightings, $29 \%$ of rough-toothed dolphin groups had at least one calf present. Rough-toothed dolphin group size was found to be homogeneous across all four regions $(F$-test $=0.345, \mathrm{df}=33 ; F 5 \%=2.89$ [Table 2]). In the Windward Islands, the roughtoothed dolphin was sometimes found in mixed schools, once associated with bot-

TABLE 1

Survey Effort and Sighting Conditions with Percentage of Total in Each Column in Parentheses

\begin{tabular}{lccccc}
\hline \hline & $\begin{array}{c}\text { Entire Study } \\
\text { Area } \\
(\%)\end{array}$ & $\begin{array}{c}\text { Region 1 } \\
(\text { Channel }) \\
(\%)\end{array}$ & $\begin{array}{c}\text { Region 2 } \\
(\text { Moorea }) \\
(\%)\end{array}$ & $\begin{array}{c}\text { Region 3 } \\
(\text { Tahiti) } \\
(\%)\end{array}$ & $\begin{array}{c}\text { Region 4 } \\
(\text { Offshore }) \\
(\%)\end{array}$ \\
\hline Parameter & 6,458 & 3,441 & 1,706 & 758 & 553 \\
Total effective effort $(\mathrm{km})$ & 864 & 482 & 213 & 117 & 52 \\
& $(13.4 \%)$ & $(14.1 \%)$ & $(12.5 \%)$ & $(15.0 \%)$ & $(9.4 \%)$ \\
Effort in Beaufort 0-1 conditions $(\mathrm{km})$ & 2,442 & 1,383 & 678 & 242 & 139 \\
& $(37.8 \%)$ & $(40.2 \%)$ & $(39.7 \%)$ & $(31.9 \%)$ & $(35.1 \%)$ \\
Effort in Beaufort 3 conditions $(\mathrm{km})$ & 3,152 & 1,576 & 815 & 399 & 362 \\
& $(48.8 \%)$ & $(45.7 \%)$ & $(45.7 \%)$ & $(52.6 \%)$ & $(65.4 \%)$ \\
\hline
\end{tabular}


TABLE 2

Number of Sightings and Average Group Size by Region Surveyed

\begin{tabular}{lcc}
\hline \hline Region & $\begin{array}{c}\text { No. of } \\
\text { Sightings }\end{array}$ & $\begin{array}{c}\text { Average Group } \\
\text { Size (SE) }\end{array}$ \\
\hline 1: Channel & 13 & 10.4 \\
2: Moorea & 14 & $(10.0)$ \\
& & 12.5 \\
3: Tahiti & 8 & $(11.2)$ \\
4: Offshore & 3 & 8.1 \\
& & $13.1)$ \\
& & $(13.1)$ \\
\hline
\end{tabular}

tlenose dolphins and twice with melonheaded whales and Fraser's dolphins. Steno bredanensis was also observed interacting with humpback whales on two occasions. Although both spinner dolphins and pilot whales are commonly found in French Polynesia (Gannier 2000), rough-toothed dolphins were never seen associated with either of these species during our surveys.

\section{Distribution}

Steno bredanensis was sometimes observed less than $100 \mathrm{~m}$ from the reef barrier and occasionally more than $30 \mathrm{~km}$ offshore, indicating a wide distribution range. When considering the entire study area, the total distributions corrected for effort indicate that $S$. bredanensis was found at a rate of 0.124 individual per kilometer. Inshore regions (regions 1 to 3 ) had a higher number of $S$. bredanensis than the offshore area (region 4), with 0.239 (Table 3) and $0.079 \pm 0.130 \mathrm{SE}$ individual per kilometer, respectively. Although sample size in the offshore region was small, this difference was significant ( $t$-test, $t=2.82, \quad \mathrm{df}=35$, $P=0.08)$.

Effort-corrected distribution of roughtoothed dolphins was considered according to distance from the barrier reef, bottom depth, and different regions sampled (Table 3). Overall, S. bredanensis was more frequently sighted $1.8-5.5 \mathrm{~km}$ from shore, with 0.422 individual per kilometer $(n=19 \pm 0.166 \mathrm{SE})$, than in the $0-1.8 \mathrm{~km}$ area, with 0.063 individual per kilometer $(n=8 \pm 0.031 \mathrm{SE})$. This difference was significant $(t$-test, $t=$ 5.44, $\left.\quad \mathrm{df}=29, \quad P=1.18 \quad 10^{-5}\right)$. Likewise, rough-toothed dolphins were more frequently sighted in depths between 1,000 and 2,000 m, with 0.190 individual per kilometer $(n=13 \pm 0.079 \mathrm{SE})$, than in the $0-1,000 \mathrm{~m}$ category, with 0.173 individual per kilometer $(n=18 \pm 0.061 \mathrm{SE})$, although this difference was not significant $(t$-test, $t=0.067, \mathrm{df}=29$, $P=0.548)$.

Effort-corrected distributions were similar off Tahiti and Moorea (regions 3 and 2), with

TABLE 3

Mean Sighting Rates for Different Categories (in Dolphins per $100 \mathrm{~km}$ of Effort)

\begin{tabular}{lllll}
\hline \hline Mean Sighting Rates $(n ; \mathrm{SE})$ & Channel & Moorea & Tahiti & $\begin{array}{c}\text { Inshore } \\
\text { (Both Islands) }\end{array}$ \\
\hline Whole region & 18.62 & 27.56 & 32.59 & 23.89 \\
& $(15 ; 8.51)$ & $(11 ; 13.47)$ & $(9 ; 13.16)$ & $(35 ; 6.93)$ \\
Distance to shore 0 to $1.8 \mathrm{~km}$ & - & 12.49 & 1.05 & 6.29 \\
& - & $(7 ; 6.73)$ & $(1 ; 0.59)$ & $(8 ; 3.12)$ \\
Distance to shore 1.8 to $5.5 \mathrm{~km}$ & - & 29.20 & 47.80 & 42.24 \\
& - & $(8 ; 17.70)$ & $(11 ; 20.17)$ & $(19 ; 16.64)$ \\
Depth 0 to $1,000 \mathrm{~m}$ & - & 19.87 & 13.60 & 17.34 \\
Depth 1,000 to $2,000 \mathrm{~m}$ & - & 23.95 & $(8 ; 5.27)$ & $(18 ; 6.12)$ \\
& & $(6 ; 13.37)$ & $(7 ; 7.67)$ & 18.98 \\
& & & & $(13 ; 7.90)$ \\
\hline
\end{tabular}


respective values of $0.326(n=9 \pm 0.132 \mathrm{SE})$ and $0.276(n=11 \pm 0.135 \mathrm{SE})$ individual per kilometer, and somewhat lower in the channel region (region 1), with a value of 0.186 $(n=15 \pm 0.085 \mathrm{SE})$ individual per kilometer (Table 3). Pairwise statistical comparison indicated that only Tahiti and the channel region were significantly different $(t$-test, $t=2.734, \mathrm{df}=20, P=0.0127)$.

\section{Seasonal Variation}

Differences in distribution were found between the colder-water season (September to November), intermediate water temperature range (December to February), and the warmer-water season (March to May). During the cold-water season (September to November), a sighting rate of only 0.10 individual per kilometer $(n=8 \pm 0.05 \mathrm{SE})$ was obtained, which was much lower than for the two other periods. In December to February the sighting rate was 0.21 individual per kilometer $(n=5 \pm 0.14 \mathrm{SE})$, which is close to the warm-season (March until May) sighting rate of $0.15(n=11 \pm 0.08 \mathrm{SE})$. However, the cold-water season estimate was probably influenced by an uneven effort distribution during that period (September-November) because sampling favored inshore waters where surveys were focused on humpback whales during the winter months.

\section{DISCUSSION}

Our distribution results from the Windward Islands suggest that rough-toothed dolphins prefer a specific habitat in French Polynesian waters. Steno bredanensis is most frequently found in water depths between 1,000 and 2,000 m, ca. 1.8 to $5.5 \mathrm{~km}$ from shore. These results do not demonstrate a purely pelagic habitat usage in this region, which is in contrast to many general reports describing $S$. bredanensis as only a deep-water species (Leatherwood et al. 1982, Leatherwood and Reeves 1983, Miyazaki and Perrin 1994). In Hawai'i $S$. bredanensis is apparently found farther offshore (Mobley et al. 2000, Baird et al. 2003) but where depths are similar to those found closer inshore in French Poly- nesia (Schlais 1984). However, water depth alone was not found to be an important factor affecting sighting rates in our study (Table 3 ), despite a probable influence on prey availability. It is not known which specific species of cephalopods and fish $S$. bredanensis in French Polynesia feeds upon. During our study rough-toothed dolphins only were visually observed feeding on epipelagic fishes (including flying fishes) during the day. Mahimahi (Coryphaena bippurus) has been suggested as a prey item of $S$. bredanensis (Pitman and Stinchcomb 2002), which would be consistent with an abundance of mahimahi in the areas of French Polynesia where roughtoothed dolphins are most commonly sighted. Inshore prey species have been suggested from stomach contents of stranded individuals in Hawai'i, but those animals may not have represented healthy animals, which are normally found offshore in that region (Miyazaki and Perrin 1994, Mobley et al. 2000). Roughtoothed dolphins are known to enter inshore waters in some areas (for example, this species is sometimes caught as bycatch in coastal gill-net fisheries off northeastern Brazil [Monteiro-Neto et al. 2000]).

In the Windward Islands of French Polynesia, our overall average sighting rate of $S$. bredanensis was 0.124 individual per kilometer. Although comparisons are difficult because survey platforms and observation protocols are specific to each study, sighting rates in other oceans do indicate lower frequencies of S. bredanensis, with estimates of 0.0047 and 0.00258 individual per kilometer in the eastern tropical Pacific and western tropical Indian Ocean, respectively (Wade and Gerrodette 1993, Ballance and Pitman 1998). Rough-toothed dolphin importance in delphinid populations may better be compared in terms of sighting frequency. Steno bredanensis ranks second in the Society Islands, with $34 \%$ of on-effort delphinid sightings (Gannier 2000). In the Marquesas, the northernmost archipelago of French Polynesia, the species ranked sixth, with a sighting frequency of $4.0 \%$ (Gannier 2002). In the Solomons, rough-toothed dolphins ranked fifth among delphinids, with a sighting frequency of 5.0\% (Shimada and Pastene 1995). 
In the Sulu Sea in the Philippines, the species also ranked fifth, with a sighting frequency of 2.9\% (Dolar et al. 1997). Steno bredanensis was ranked as the ninth most common cetacean species sighted in both the eastern tropical Pacific and the western tropical Indian Ocean (Wade and Gerodette 1993, Ballance and Pitman 1998). Hence from results available in the literature, French Polynesia, and in particular the Windward Islands, appears to be a favored area for S. bredanensis. Another region where $S$. bredanensis sighting frequency rates are greater than $20 \%$ has been identified in similar water depths off the Hawaiian islands of Kaua'i and Ni'ihau (Baird et al. 2003). Certainly, this species is present around many small oceanic islands in warm temperate to tropical regions and perhaps is found in habitat similar to that of Tahiti/Moorea and Kaua'i/Ni'ihau more abundantly than previously thought.

Our seasonal distribution results indicate surprising differences in that the lowest seasonal sighting rate was obtained during the cold-water season and the highest sighting rate during intermediate water temperature values (December to February). This does not agree with relative abundance estimates of Gannier (2000), which indicated that delphinids are generally three times more likely to be sighted during cold-water periods as in the warm season in the Society Islands. However, the melon-headed whale and Fraser's dolphin account for two of these four delphinid species, and those species were sighted in very large groups during the coldwater season, influencing the results presented for all delphinid species in Gannier (2000). It is also possible that our results for $S$. bredanensis seasonal distributions are at least partially affected by an unequal sampling effort regarding depth and distance from shore between the seasons. During the cold-water period our efforts were more concentrated on shallower areas, because surveys were sometimes focused on humpback whales during that portion of the year. Regardless of season, our results indicate that in French Polynesia $S$. bredanensis is most commonly found at a distance of 1.8 to $5.5 \mathrm{~km}$ from the barrier reef in water depths of ca. 1,000-2,000 m.
The Windward Islands are located in an oceanic region where oligotrophy is the rule, with a very deep thermocline (Longhurst 1999). However, small-scale biomass production may be generated by interaction between currents and oceanic islands (Heywood et al. 1990). This may account for higher relative abundance close to the Windward Islands, although $S$. bredanensis is also likely to favor areas where food availability is higher because of ocean floor proximity.

\section{ACKNOWLEDGMENTS}

We express our thanks to Claude Payri and the Laboratory of Marine Ecology at the Université de la Polynésie française for the logistical assistance that made this project possible.

\section{Literature Cited}

Aitchison, J., and J. A. C. Brown. 1957. The lognormal distribution. Cambridge University Press, Cambridge.

Aristegui, J. P., A. Tett, G. HernandezGuerra, M. F. Batserretxea, K. Montero, P. Wild, S. Sangra, M. Hernandez-Leon, J. A. Canton, M. Garcia-Braun, S. Pacheco, and E. D. Barton. 1997. The influence of island-generated eddies on chlorophyll distribution: A study of mesoscale variation around Gran Canaria. Deep-Sea Res. I. 44:71-97.

$\mathrm{Au}, \mathrm{D}$. W. K., and W. L. Perryman. 1985. Dolphin habitats in the eastern tropical Pacific. Fish. Bull. 83:623-643.

Baird, R. W., D. J. McSweeney, D. L. Webster, A. M. Gorgonne, and A. D. Ligon. 2003. Studies of odontocete population structure in Hawaiian waters: Results of a survey through the main Hawaiian Islands in May and June 2003. Reports prepared under contract no. AB133F-02-CN-0106. Available from the National Oceanic and Atmospheric Administration, Western Administrative Support Center, 7600 Sand Point Way NE, Seattle, Washington 98115.

Ballance, L. T., and R. L. Pitman. 1998. Cetaceans of the western tropical Indian 
Ocean: Distribution, relative abundance, and comparisons with cetacean communities of two other tropical ecosystems. Mar. Mamm. Sci. 14 (3): 429-459.

Buckland, S. T., D. R. Anderson, K. P. Burnham, and J. L. Laake. 1993. Distance sampling: Estimating abundance of biological populations. Chapman and Hall, London.

Dolar, M. L., W. F. Perrin, A. A. S. P. Yaptinchay, S. A. B. H. Jaaman, M. D. Santos, M. N. Alava, and M. S. B. Suliansa. 1997. Preliminary investigation of marine mammal distribution, abundance and interactions with humans in southern Sulu Sea. Asian Mar. Biol. 14:61-81.

Gannier, A. 2000. Distribution of cetaceans off the Society Islands (French Polynesia) as obtained from dedicated survey. Aquat. Mamm. 26 (2): 111-126.

. 2002. Cetaceans of the Marquesas Islands (French Polynesia): Distribution and relative abundance as obtained from a small boat dedicated survey. Aquat. Mamm. 28 (2): 198-210.

Hewitt, R. P. 1985. Reaction of dolphins to a survey vessel effects on census data. Fish. Bull. 83:187-193.

Heywood, K. J., E. D. Barton, and J. H. Simpson. 1990. The effects of flow disturbance by an oceanic island. J. Mar. Res. 48:55-73.

Hiby, A., and P. S. Hammond. 1989. Survey techniques for estimating abundance of cetaceans. Rep. Int. Whaling Comm. Spec. Issue 11:47-80.

Leatherwood, S., and R. R. Reeves. 1983. The Sierra Club handbook on cetaceans. Sierra Club Books, San Francisco.

Leatherwood, S., R. R. Reeves, W. F. Perrin, and W. E. Evans. 1982. Whales, dolphins and porpoises of the eastern North Pacific and adjacent arctic waters. NOAA Tech. Rep. NMFS Circ. 444:1-245.

Longhurst, A. R. 1999. Ecological geography of the sea. Academic Press, San Diego.

Massé, J., and Y. Cadiou. 1994. Oedipe. User's guide. Ifremer, Nantes, France.

Miyazaki, N., and W. F. Perrin. 1994. Rough-toothed dolphin Steno bredanensis
(Lesson, 1828). Pages 1-21 in S. H. Ridgway and R. J. Harrison, eds. Handbook of marine mammals. Vol. 5. The first book of dolphins. Academic Press, London.

Mobley, J. R., S. S. Spitz, K. A. Forney, R. Grotefendt, and P. H. Forestell. 2000. Preliminary results of 1993-98 aerial surveys. Southwest Fisheries Science Center Administrative Report LJ-OO-14C. Available from SWFC, P.O. Box 271, La Jolla, California 92038.

Monteiro-Neto, C., T. T. Alves-Junior, F. J. Capibaribe Avila, A. A. Campos, A. F. Costa, C. P. Negrao Silva, and M. A. A. Furtado-Neto. 2000. Impact of fisheries on the tucuxi (Sotalia fluviatilis) and roughtoothed dolphin (Steno bredanensis) populations off Cearà state, northeastern Brazil. Aquat. Mamm. 26 (1): 49-56.

Mullin, K. D., W. Hoggard, C. L. Roden, R. R. Lohoenfener, and C. M. Rogers. 1994. Cetaceans on the upper continental slope in the north-central Gulf of Mexico. Fish. Bull. 92:773-786.

Pennington, M. 1983. Efficient estimators of abundance, for fish and plankton surveys. Biometrics 39:281-286.

Pennington, M., and P. Berrien. 1984. Measuring the precision of estimates of total egg prodution based on plankton surveys. J. Plankton Res. 6 (5): 869-879.

Pitman, R. L., and C. Stinchcomb. 2002. Rough-toothed dolphins (Steno bredanensis) as predators of mahimahi (Coryphaena hippurus). Pac. Sci. 56:447-450.

Schlais, J. F. 1984. Thieving dolphins: A growing problem in Hawaii's fisheries. Sea Front. 30 (5): 293-298.

Shimada, H., and L. A. Pastene. 1995. Report of a sighting survey off the Solomon Islands with comments on Bryde's whale distribution. Rep. Int. Whaling Comm. 45:413-417.

Wade, P. R., and T. Gerrodette. 1993. Estimates of cetacean abundance and distribution in the eastern tropical Pacific. Rep. Int. Whaling Comm. 43:477-493.

Watkins, W. A., P. Tyack, and K. E. Moore. 1987. Steno bredanensis in the Mediterranean Sea. Mar. Mamm. Sci. 3 (1): 78-82. 